\title{
Current Trends of Geriatric Depression at an Indian Tertiary Care Center
}

\author{
Akash Rajender $^{1 *}$, Krishna Kanwal ${ }^{2}$, Gaurav R ${ }^{3}$
}

\section{ABSTRACT}

Background: Aging is a progressive process beginning with life \& ending with death. There is a massive growth in elderly population \& age associated diseases. Depression is frequently associated with aging, associated comorbidities \& treatment compliance in this fragile age group. Aims \& Objective: To study prevalence of depression in elderly using Geriatric Depression Scale (GDS) and its associated risk factors. Method: Three hundred elderly ( $\geq 60$ years) patients were assessed at Mahatma Gandhi Medical College \& Hospital, Jaipur in an observational, cross sectional study using Geriatric Depression Scale (GDS). Correlation with associated risk factors were evaluated. Statistical analysis was done using SPSS version 12.0. Results: Prevalence of depression was 29.3\% of which 62 (20.67\%) were mildly depressed and 26 (8.67\%) were severely depressed. Depression was significantly higher in elderly subjects with comorbid chronic disease (p 0.0001), inadequate sleep (p 0.001), absent social participation (p 0.002) and in those who did not engage themselves in day time work or hobbies (p 0.0002). Conclusions: Depression is common in elderly, its undiagnosed \& overlooked. Prevention of risk factors \& early diagnosis may significantly reduce morbidity, mortality \& improve quality of life.

Keywords: Depression, Elderly, Prevalence, Risk Factors.

Aging is a progressive process which begins with life \& continues throughout life cycle, finally ending with death [1]. It is a universal phenomenon [2] resulting in a process called “demographic transition” [3] i.e. is a shift from high mortality and fertility to low, thus causing an increase in elderly population.

India, is presently in demographic transition with 72 million above 60 years of age, which is expected to increase to 179 million in 2031 and further to 301 million in 2051. This massive increase in geriatric population will put an enormous pressure on health care services [4]. India

\footnotetext{
${ }^{1}$ Assistant Professor, Department of General Medicine, Mahatma Gandhi Medical College \& Hospital, Jaipur

${ }^{2}$ Professor \& Head, Department of Psychiatry, Mahatma Gandhi Medical College \& Hospital, Jaipur

${ }^{3}$ Assistant Professor, Department of Psychiatry, SMS Medical college, Jaipur

*Responding Author

(C) 2016 I A Rajender, K Kanwal, Gaurav R; licensee IJIP. This is an Open Access Research distributed under the terms of the Creative Commons Attribution License (http://creativecommons.org/licenses/by/2.0), which permits unrestricted use, distribution, and reproduction in any Medium, provided the original work is properly cited.
} 


\section{Current Trends of Geriatric Depression at an Indian Tertiary Care Center}

being a developing nation needs to be prepared for this challenge, with more knowledge on the disease \& comorbidity pattern in this population at risk. Early diagnosis and treatment remains the mainstay to reduce the burden of this disease.

Elderly being economically unproductive, are commonly neglected[5], stressed \& more prone to mental disorders [3] of which depression is common. Depression is difficult to diagnose, especially when associated as a co morbidity in chronic diseases of elderly. Depression leads to an increase in morbidity, mortality, health care utilization, treatment cost, along with a reduction in quality of life [6].Depressed elderly adhere less to diet, exercise, and medication. Depression is projected to become the second-leading cause of disease burden after ischemic heart disease by the year 2020. [7]

Early diagnosis and treatment remains the mainstay to reduce depression burden in elderly. Studies on depressed elderly are very few in India, this study is an attempt to diagnose elderly with depression, determine factors responsible \& suggest preventive measures.

\section{METHOD}

\section{Source of Data}

In our study, 300 patients with age $\geq 60$ years, were randomly selected at Mahatma Gandhi Medical College \& Hospital, Jaipur, Rajasthan, India; over a study period from October 2013 to November 2014. Patients with known psychiatric comorbidity, psychiatric treatment (pharmacological or non-pharmacological) or severe unstable condition \& associated conditions interfering with interview were excluded from the study. A formal written consent was taken from all patients.

\section{General Protocol}

Patient's clinical profiles were reviewed and information was procured pertaining to demographic aspects, past medical history, and use of medications. Geriatric depression scale (GDS) was used for diagnosis of major depression \& its severity. GDS screens for seven characteristics of depression in elderly, which are somatic concerns, lower affect, cognitive impairment, feelings of discrimination, impaired motivation, lack of future orientation and lack of self-esteem. It consists of 30 questions with a maximum score of 30. A score of 10 and more were diagnosed with depression. Socioeconomic profile \& risk factors for depression were evaluated with pre-structured Performa.

\section{Statistical Analysis}

Descriptive statistics was used for analysis. Chi-square test was used to find out the association between two variables and $\mathrm{p}<0.05$ was considered to be statistically significant. Statistical analysis was carried out using the SPSS 12.0. 


\section{RESULTS}

Of the 300 study subjects who participated in the study, 186 (62\%) were females and 114 (38\%) were males. 88 (29.33\%) were diagnosed with major depression (GDS score $\geq 10$ ).

Table 1 summarizes the socio-demographic characteristics of the elderly studied. The mean age of the studied subjects was 66.7 years. Most of the sample consisted of Hindus (238, 79.33\%), illiterates (164, 54.67\%), non-working (177, 59\%), married (206, 68.67\%) \& living in joint families (115, 38.33\%). More than one third 113 (37.67\%) belonged to class IV SES (Modified B.G. Prasad Classification 2011).

Of the 300, overall prevalence of depression was 64 (29.36\%), of which 62 (20.67\%) were mildly depressed and 26 (8.67\%) were severely depressed. Female gender \& Age group $\geq 70$ years were more depressed. Depression showed a significant association with age $\geq 70$ years, illiterates, lower socio-economic status (SES) \& single (widowed/unmarried/divorced) marital status. An inverse relationship was seen between SES and depression, with depression being higher in low socioeconomic group. Association of socio-demographic characteristics with depression is shown in Table 3.

On evaluating the risk factors leading to depression in elderly, 113 (53.3\%) physically active subjects were not depressed as compared to 66 (75\%) inactive subjects suffering from depression (p 0.0001).

Depression was significantly higher in elderly subjects with comorbid chronic disease (p 0.0001), inadequate sleep (p 0.001), absent social participation (p 0.002) and in those who did

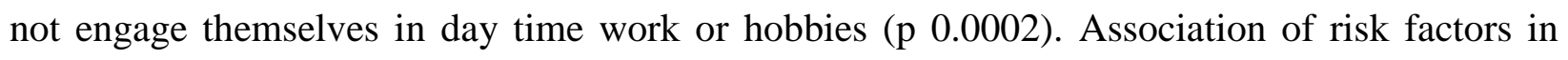
causation of depression in elderly is discussed in Table 4.

Table 1: Socio- Demographic Characteristics of Elderly subjects

\begin{tabular}{|l|l|l|}
\hline \multicolumn{2}{|l|}{ Characteristic } & $\begin{array}{l}\text { TOTAL (n=300) } \\
\text { No. (\%) }\end{array}$ \\
\cline { 2 - 3 } Sex & Male & $114(38)$ \\
\hline \multirow{2}{*}{ Age } & Female & $186(62)$ \\
\hline \multirow{3}{*}{ Religion } & $60-69$ years & $204(68)$ \\
\cline { 2 - 3 } & $\geq 70$ years & $96(32)$ \\
\hline \multirow{2}{*}{ Education status } & Hindu & $238(79.33)$ \\
\cline { 2 - 3 } & Muslim & $58(19.33)$ \\
\cline { 2 - 3 } & Others & $4(1.33)$ \\
\hline \multirow{3}{*}{ Occupation } & Illiterates & $164(54.67)$ \\
\cline { 2 - 3 } & Literates & $136(45.33)$ \\
\cline { 2 - 3 } & Non Working & $177(59)$ \\
\cline { 2 - 3 } & Working & $123(41)$ \\
\hline
\end{tabular}




\begin{tabular}{|l|l|l|}
\hline Socio-economic Status $*$ & Class I & $28(9.33)$ \\
\cline { 2 - 3 } & Class II & $69(23)$ \\
\cline { 2 - 3 } & Class III & $79(26.33)$ \\
\cline { 2 - 3 } & Class IV & $113(37.67)$ \\
\cline { 2 - 3 } & Class V & $11(3.67)$ \\
\hline \multirow{4}{*}{ Family Type } & Nuclear & $94(31.33)$ \\
\cline { 2 - 3 } & Joint & $115(38.33)$ \\
\cline { 2 - 3 } & Three Generations & $91(30.33)$ \\
\cline { 2 - 3 } & Widowed/ Unmarried/ Divorced & $94(31.33)$ \\
\cline { 2 - 3 } & Married & $206(68.67)$ \\
\hline
\end{tabular}

* Modified B.G. Prasad Classification 2011

Table 2: Prevalence of Major Depression in Elderly subjects using Geriatric Depression scale (GDS)

\begin{tabular}{|l|l|l|l|}
\hline GDS Score & $\begin{array}{l}\text { Males } \\
\text { No. (\%) }\end{array}$ & $\begin{array}{l}\text { Females } \\
\text { No. (\%) }\end{array}$ & $\begin{array}{l}\text { Total } \\
\text { No. (\%) }\end{array}$ \\
\hline Normal (0-9) & $85(74.56)$ & $127(68.28)$ & $212(70.66)$ \\
\hline Mild (10-19) & $24(21.05)$ & $38(20.43)$ & $62(20.67)$ \\
\hline Severe (20-30) & $5(4.39)$ & $21(11.29)$ & $26(8.67)$ \\
\hline Total & $114(38)$ & $186(62)$ & $300(100)$ \\
\hline
\end{tabular}

Table 3: Correlation of Depression with Sociodemographic characteristics of Elderly

\begin{tabular}{|c|c|c|c|c|}
\hline \multicolumn{2}{|l|}{ Characteristics } & $\begin{array}{l}\text { Without } \\
\text { Depression } \\
(\mathrm{n}=212)\end{array}$ & $\begin{array}{l}\text { With } \\
\text { Depression } \\
(\mathrm{n}=\mathbf{8 8})\end{array}$ & p value \\
\hline \multirow[t]{2}{*}{ Sex } & Males & 85 (40.09) & 29 (32.95) & \multirow[t]{2}{*}{0.292} \\
\hline & Females & 127 (59.91) & $59(67.05)$ & \\
\hline \multirow[t]{2}{*}{ Age } & $60-69 \mathrm{yrs}$ & $150(70.75)$ & 54 (61.36) & \multirow[t]{2}{*}{$0.04 *$} \\
\hline & $\geq 70$ yrs & $58(27.36)$ & 38 (42.18) & \\
\hline \multirow{2}{*}{$\begin{array}{l}\text { Education } \\
\text { Status }\end{array}$} & Illiterates & 133 (62.74) & $31(35.22)$ & \multirow[t]{2}{*}{ 0.009* } \\
\hline & Literates & 99 (46.7) & 37 (42.04) & \\
\hline \multirow{2}{*}{ Occupation } & Non-Working & $119(56.13)$ & 58 (65.91) & \multirow[t]{2}{*}{0.08} \\
\hline & Working & $93(43.86)$ & $30(34.09)$ & \\
\hline \multirow{3}{*}{$\begin{array}{l}\text { Socio- } \\
\text { economic } \\
\text { status }\end{array}$} & Class I+II & $80(37.74)$ & 17 (19.32) & \multirow[t]{3}{*}{$0.0005^{*}$} \\
\hline & Class III & 57 (26.89) & $22(25)$ & \\
\hline & Class IV+V & 70 (33.02) & $54(61.36)$ & \\
\hline \multirow[t]{3}{*}{ Family Type } & Nuclear & $63(29.72)$ & $31(35.23)$ & \multirow[t]{3}{*}{0.88} \\
\hline & Joint & $81(38.21)$ & 34 (38.63) & \\
\hline & Three Generations & 68 (32.07) & $23(26.14)$ & \\
\hline \multirow[t]{2}{*}{ Marital Status } & $\begin{array}{l}\text { Widowed/ unmarried/ } \\
\text { divorced }\end{array}$ & $49(23.11)$ & 45 (51.14) & \multirow[t]{2}{*}{$0.0001^{*}$} \\
\hline & Married & 157 (74.06) & 49 (55.68) & \\
\hline
\end{tabular}

$* \mathrm{p} \leq 0.05$ 
Table 4: Risk Factors for depression in Elderly

\begin{tabular}{|c|c|c|c|c|}
\hline \multicolumn{2}{|l|}{ Risk Factors } & $\begin{array}{l}\text { Without Depression } \\
(n=212)\end{array}$ & $\begin{array}{l}\text { With Depression } \\
(n=88)\end{array}$ & p value \\
\hline \multirow[t]{2}{*}{ Addiction } & Yes & $88(41.98)$ & $46(52.27)$ & \multirow[t]{2}{*}{0.08} \\
\hline & No & $123(58.02)$ & 42 (47.73) & \\
\hline \multirow[t]{2}{*}{ Physical Activity } & Active & $113(53.3)$ & $22(25)$ & \multirow[t]{2}{*}{$0.0001^{*}$} \\
\hline & Inactive & $99(46.7)$ & $66(75)$ & \\
\hline \multirow{2}{*}{$\begin{array}{l}\text { Comorbid Chronic } \\
\text { Disease }\end{array}$} & Absent & $166(78.3)$ & $40(45.45)$ & \multirow[t]{2}{*}{$0.0001^{*}$} \\
\hline & Present & $46(21.7)$ & 48 (54.55) & \\
\hline \multirow[t]{2}{*}{ Social Participation } & Present & $162(76.42)$ & 49 (55.68) & \multirow[t]{2}{*}{$0.002 *$} \\
\hline & Absent & $50(23.58)$ & $39(44.32)$ & \\
\hline \multirow[t]{2}{*}{ Daytime Involvement } & Engaged & $147(69.34)$ & $33(37.5)$ & \multirow[t]{2}{*}{$0.0002 *$} \\
\hline & Not Engaged & $65(30.66)$ & $55(62.5)$ & \\
\hline \multirow{2}{*}{$\begin{array}{l}\text { Recreational activity } \\
\text { participation }\end{array}$} & Yes & $133(62.74)$ & $58(65.91)$ & \multirow[t]{2}{*}{0.72} \\
\hline & No & $79(37.26)$ & $30(34.09)$ & \\
\hline \multirow[t]{2}{*}{ Sleep Pattern } & Satisfied & $121(57.1)$ & $17(19.32)$ & \multirow[t]{2}{*}{$0.001 *$} \\
\hline & Not Satisfied & $91(42.91)$ & $71(80.68)$ & \\
\hline
\end{tabular}

$* \mathrm{p} \leq 0.05$

\section{DISCUSSION}

Depression in elderly is a commonly missed, undiagnosed, unrecognised clinical diagnosis. It is mostly assumed to be a normal response to aging, comorbidity, physical losses or other life events. It causes excess physical \& psychological disability and has an adverse impact on physical health.[11]

In our study, almost one third of elderly (29.33\%) suffered from depression. Those elderly subjects found to be prone for depression, were found to be commonly associated with several risk factors were like higher age, low socio-economic status, single or widowed marital status, physical inactivity, presence of chronic diseases, lack of social participation and inadequate sleep.

In our study, females were more depressed than their male counterparts (67.05\% vs. 32.95\%), this can be attributed to Indian socio-cultural factors \& psychological factors, as women throughout their lifetime face more stressful events and have a greater sensitivity towards them. Similarly, the prevalence of depression has been found to be higher in elderly women in other Indian studies done by Jain RK [12], Rajkumar AP et al [13] and by Poongothai S et al [14]. On the contrary, Sandhya GI et al [4] showed that the prevalence of depression was lower in females (22.9\%) when compared to males (29.1\%) in a study done in a rural community in South Kerala.

In our present study, single (widowed/unmarried/divorced) elderly subjects showed a significant (p 0.001) higher prevalence of depression (51.14\%). In late life, more emotional support is 


\section{Current Trends of Geriatric Depression at an Indian Tertiary Care Center}

required as to face challenges posed by physical \& psychological stressors, debility, worsening of chronic disease condition due to improper treatment compliance\& neglect. Death of a spouse causes irreparable psychological damage, making the vulnerable to depression. Adjustment disorders are common in late life divorce or separation, leading to depressive symptomatology. Single individuals, lack the much required support of spouse and children in late life. Kamble SV et al[5] in a study showed similar results, that marital disruption, widowhood and single status were associated with a higher prevalence of depression in both men and women.

Elderly subjects with lower socio-economic status showed a higher prevalence of depression in our study. Similar results were showed in several Indian studies by Jain RK et al [12] and Rajkumar AP et al [13]. This can be attributed to increased stress, insecurity, uncertainties to future, poor accessibility to health care system \& neglect of chronic disease process causing its worsening. Hence making them more prone for depression.

Three forth of the depressed subjects (75\%) were physically inactive and more than half (54.55\%) had at least one chronic disease. Poor physical activity can make an individual more prone to depression owing to worsening to worsening of physical debility, chronic disease, visiospatial coordination \& sensory deprivation. Lack of physical activity makes the individual more dependent on care takers, curbs independence, lowers self-esteem, enormously changing the way a person lives, copes to stressors and his perception of himself $\&$ his surroundings. Similar results on association of poor physical health with depression was seen in Seby $\mathrm{K}$ et al [4]and Rajkumar AP et al [13].

Lack of social participation showed an association with depression in our study. Social participation maintains the liveliness and gives a feeling of bonding with the group or community. Lack of social participation makes an individual alone, gives a feeling of worthlessness \& emptiness. Sandhya GI et al [4] had similar results in a study done in rural community in South Kerala

Disturbed sleep pattern as seen among $80.68 \%$ subjects was also a statistically significant risk factor leading to depression in present study, as also stated by Jain RK et al[12]. Depression in elderly is both preventable \& treatable as observed by Korte $\mathrm{J}$ et al.[15]. Its easy diagnosis, prognostic significance, impact on quality of life $\&$ health care cost in elderly population makes it an important issue to address in this population.

\section{CONCLUSION}

India in this era of demographic transition, has an enormous geriatric population prone to depression. Presently one in every three elderly subjects suffer from major depression. Depression is common comorbidity associated with chronic diseases \& often overlooked attributing to disease related factors. Understanding of its risk factors \& making consolidated 


\section{Current Trends of Geriatric Depression at an Indian Tertiary Care Center}

efforts towards its diagnosis \& treatment may go a long way in reducing morbidity, mortality \& quality of life of elderly.

\section{DECLARATIONS}

No Funding sources

Conflict of interest: None Declared

Ethical approval: The study was approved by the institutional ethics committee

\section{REFERENCES}

1. Singh A, Misra N. Loneliness, depression and socialibility in old age. Ind Psychiatry J 2009;18(1):51-55.

2. Kumar V. Aging in India- an overview. Indian J Med Res 1997;106:257-264.

3. Seby K, Chaudhury S, Chakraborty R. Prevalence of psychiatric and physical morbidity in an urban geriatric population. Indian J Psychiatry 2011;53(2):121-7.

4. Sandhya GI. Geriatric Depression and Related Factors-A Cross sectional Study from a Rural Community in South Kerala. Journal of The Indian Academy of Geriatrics 2010;6(2):6163.

5. Kamble SV, Dhumale GB, Goyal RC, Phalke DB, Ghodke YD. Depression among Elderly Persons in a Primary Health Centre Area in Ahmednagar, Maharashtra. Indian J Public Health 2009;53(4):253-255.

6. Sherina M, Rampal SL, Aini M, Norhidayati MH. The prevalence of depression among elderly in an urban area of Selangor, Malaysia. The International Medical Journal 2005;4(2):57-63.

7. Barua A, Kar N. Screening for depression in elderly Indian population. Indian J Psychiatry 2010;52(2):150-3.

8. Romanelli J. The significance of depression in older patients after myocardial infarction. Journal of the American Geriatrics Society 2000;50(5):969-970.

9. Yesavage JA, et al. Development and validation of a geriatric depression screening scale: a preliminary report. J Psychiatr Res 1983;17(1):37-49.

10. Mahajan BK, Gupta MC. Social Environment. In: Mahajan BK, Gupta MC, ed. Textbook of Preventive and Social Medicine, 3rd edition, New Delhi: M/S Jaypee Brothers;2003:117118.

11. Khattri KB, Nepal MK. Study of depression among geriatric population in Nepal. Nepal Med Coll J 2006;8(4):220-223.

12. Jain RK, Aras RY. Depression in Geriatric Population in Urban Slums of Mumbai. Indian J Public Health 2007;51(2):112-3.

13. Rajkumar AP, Thanagadurai P, Senthilkumar P, Gayathri K, Prince M, Jacob KS. Nature, prevalence and factors associated with depression among elderly in a rural South Indian Community. Int Psychogeriatr 2009;21(1):372-8.

14. Poongothai S, Pradeepa R, Ganesan A, Mohan V. Prevalence of Depression in a Large Urban South Indian Population-The Chennai Urban Rural Epidemiology Study (Cures70). PLoSONE 2009;4(9):e7185. doi:10.1371/journal.pone.0007185

15. Korte J, Bohlmeijer ET, Smit F. Prevention of depression and anxiety in later life: design of a randomized controlled trial for the clinical and economic evaluation of a life-review intervention. BMC Public Health 2009;9:250. 
How to cite this article: A Rajender, K Kanwal, Gaurav R (2016) Current Trends of Geriatric Depression at an Indian Tertiary Care Center, International Journal of Indian Psychology, Volume 3, Issue 3, No. 5, DIP: 18.01.084/20160303 